\title{
Cell Suspension and In Vitro Production of Colchicine in Wild Colchicum Hierosolymitanum Feib
}

\author{
Nidal Q. Daradkeh ${ }^{1}$, Rida A. Shibli ${ }^{2,}$, Ibrahim M. Makhadmeh ${ }^{3}$, Feras Alali ${ }^{4}$ and Tamara S. \\ Al-Qudah ${ }^{5}$ \\ ${ }^{1}$ National Center for Agriculture Research and Extension, Baqa'a, Jordan \\ ${ }^{2}$ Deaprtment of Horticulture and Agronomy, Faculty of Agriculture, The University of Jordan, Amman, Jordan \\ ${ }^{3}$ Department of Plant Production, Faculty of Agriculture, Jordan University of Science and Technology \\ ${ }^{4}$ Faculty of Pharmacy, Jordan University of Science and Technology \\ ${ }^{5}$ Hamdi Mango Center for Scientific Research (HMCSR), The University of Jordan, Amman, Jordan
}

\begin{abstract}
Callus was induced from seeds of Colchicum hierosolymitanum Feib inoculated on the surface of MS media supplemented with $0.45 \mu \mathrm{M} 2$, 4-dichlorophenoxyacetic acid under dark conditions. Then callus was cultured on MS media supplemented with $4.52 \mu \mathrm{M} \mathrm{2,4-dichlorophenoxyacetic} \mathrm{for} \mathrm{growth} \mathrm{and} \mathrm{maintenance.} \mathrm{Friable} \mathrm{callus} \mathrm{from} \mathrm{the} \mathrm{fourth}$ generation was transferred to liquid MS media supplemented with $0.54 \mu \mathrm{M}$ 1-naphthaleneacetic acid to form cell suspension. Cells were successfully subcultured every 27 days on the same liquid media supplemented with $0.54 \mu \mathrm{M} 1$ naphthaleneacetic acid. Higher concentration $(9 \mu \mathrm{M})$ of 6-benzyladenine with $0.45 \mu \mathrm{M} 2$, 4-dichlorophenoxyacetic acid resulted in higher cells fresh weight, while 1-naphthaleneacetic acid combinations with 6-benzyladenine had no effect on cell growth. On the other hand, the time for subculturing the cells into new fresh liquid media was determined to be after 27 days of incubation. (-) -Colchicine was identified in callus and cell suspension of $C$. hierosolymitanum by performing HPLC analysis against standard. Different ratios of $\mathrm{NH}^{+4}: \mathrm{NO}^{-3}$ were used to study their effect on (-)-colchicine content, the highest colchicine content of $0.070 \mathrm{mg} \mathrm{g}^{-1} \mathrm{DW}$ was obtained at $30 \mathrm{mM} \mathrm{NH}_{4}{ }^{+}$of total nitrogen. Colchicine alkaloid was highest, $0.090 \mathrm{mg} \mathrm{g}^{-1} \mathrm{DW}$, at $0.1 \mathrm{M}$ of sucrose after 4 weeks incubation. (-) - Colchicine alkaloid was not detected in callus grown on sucrose free media. Maximum production of colchicine, $0.235 \mathrm{mg} \mathrm{g}^{-1} \mathrm{DW}$, was obtained in callus extracts of 60 days old callus grown under dark conditions. Cell suspension had $0.012 \mathrm{mg}$ g-1 DW (-) -colchicine from suspended cells grown under dark. (-) -Colchicine content of callus incubated under dark $\left(0.095 \mathrm{mg} \mathrm{g}^{-1} \mathrm{DW}\right)$ was higher than light $\left(0.070 \mathrm{mg} \mathrm{g}^{-1} \mathrm{DW}\right)$ condition.
\end{abstract}

Keywords: Callus, Cell suspension, (-)-Colchicine, HPLC analysis.

\section{INTRODUCTION}

The genus Colchicum belongs to the colchicaceae family. It is mainly distributed in the Mediterranean region extending as far as the mountains of Pakistan and Middle Asia [1]. The medicinal value of colchicum is due to the presence of (-)-colchicine, the main alkaloid, which was isolated from all species of colchicum. It is widely used in breeding studies and as drug to treat gout [2-4]. Colchicum hierosolymitanum Feib is a species found in Jordan and it is a slow propagated species because it has low germination rate [5]. It faces many threats to be extinct totally from the wild. So the use of tissue culture techniques is appropriate alternative for rapid multiplication and sustainable growth of slow propagation species like colchicum [6,7]. Callus and suspension cell cultures are of the most valuable commercial

*Address correspondence to this author at the Deaprtment of Horticulture and Agronomy, Faculty of Agriculture, The University of Jordan, Amman, Jordan; Tel: 9626535 5000; Fax: 9626535 5577;

E-mail: r.shibli@ju.edu.jo sources for the synthesis of medicinal substances [8]. In addition, the production of secondary metabolites by cell cultures is considered a promising alternative to intact plant [9].

(-)-Colchicine, is a phenylethyl isoquinoline derived alkaloid, and it is a poisonous, lipid-soluble alkaloid with a unique 7-membered aromatic tropolone ring [10-12]. It has a venerable history and clinically used treatment of gout [13]. More recently, (-)-colchicine has been used to treat Familial Mediterranean Fever, inflammatory dermatomes, sweet's syndrome, scleroderma and Behcet's disease [14, 15].

Several studies in the literature were reported to study ()-colchicine content in pharmaceutical preparations, biological fluids and plant extracts [5, 16-19]. Production of colchicine alkaloid by plant tissue cultures was first investigated in suspension cultures of Colchicum autumnale $[20,21]$. There are some studies on the in vitro production of colchicines from colchicum species like Gloriosa superb, in which colchicine content was enhanced and increased in root cultures by treatment with $p$-coumaric acid and tyramine [22]. But there are no reports on the in vitro study of 
colchicine in Colchicum hierosolymitanum Feib. This study was carried out to develop a protocol for cell suspension and production of (-)-colchicine alkaloid from both callus and cell suspension cultures in Colchicum.

\section{MATERIALS AND METHODS}

Callus induction and culture. Seeds of Colchicum hierosolymitanum were collected from wild grown plants in north Jordan (Erhaba, Irbid) located between $32^{\circ} 22^{\prime} \mathrm{N}$ and $35^{\circ} 49^{\prime} \mathrm{E}$. The collected material was identified by the Genetic Resources Unit at the National Center for Agriculture Research and Extension (NCARE), Baqa, Jordan. Seeds were thoroughly washed under running tap water for 20 minutes with few drops of mild detergent. Then antiseptic surface sterilized by solution of $4.0 \%$ sodium hypochlorite plus two drops of Tween-20 for 15 minutes (under the laminar - air flow cabinet), and were then rinsed with autoclaved distilled water for three times ( $5 \mathrm{~min}$. each). Seeds were transferred into $70 \%(\mathrm{~V} / \mathrm{V})$ ethanol solution for 30 seconds and then rinsed with sterile distilled water 3 times (5 min. each). In all experiments, MS media (Murashige and Skoog, 1962) [23] with 30g/L were used and $\mathrm{pH}$ was adjusted to 5.8 using $\mathrm{NaOH}$ or $\mathrm{HCl}(1.0 \mathrm{~N}$ each). Eventually, $8.0 \mathrm{~g} / \mathrm{L}$ Difco-Bacto agar was added to the solid media.

Surface sterilized seeds were inoculated into $15 \times 150 \mathrm{~mm}$ test tube, one seed in each test tube containing $10 \mathrm{ml}$ of MS media (Murashige and Skoog 1962), [23] supplemented with $0.45 \mu \mathrm{M} \mathrm{2,} \mathrm{4-dichlorophenoxyacetic} \mathrm{(2,4-D)} \mathrm{for} \mathrm{callus}$ induction, then the callus was transferred to the surface of MS medium containing $4.52 \mu \mathrm{M}$ 2,4-D for further callus growth and incubated at $24 \pm 2{ }^{\circ} \mathrm{C}$ in dark inside the growth room chamber which has a standard conditions of light and temperature. Calli (Approx. $500 \mathrm{mg}$ ) were subculture on hormone free fresh MS media in dark to detect the effect of subculture time on callus growth. Callus color, texture and diameters were recorded every week through 60 days. Each treatment consisted of 5 completely randomized replicates ( each replicate consists of $15 \times 150 \mathrm{~mm}$ test tube with $10 \mathrm{ml}$ of MS media and has approx. $500 \mathrm{mg}$ of calli) for callus induction experiment.

Cell Suspension Culture. Cell suspension cultures were initiated by inoculating approximately 1.0 grams of fresh friable callus into $50 \mathrm{ml}$ of MS liquid media over a rotary shaker at100 rpm. Media for suspension culture was supplemented with $(0,0.45 \mu \mathrm{M}) 2$, 4-D or $(0.0,0.54 \mu \mathrm{M}) 1$ naphthaleneacetic acid (NAA) in combination with different levels $(0.0,2,22,3.11,9 \mu \mathrm{M})$ of 6-benzyladenine (BA). Cultures were maintained in $250 \mathrm{ml}$ Erlenmeyer flasks and were incubated on rotary shaker $(100 \mathrm{rpm})$ under dark condition at $24 \pm 2{ }^{\circ} \mathrm{C}$ inside the growth room chamber. Cells were transferred into liquid MS media supplemented with $(0.54 \mu \mathrm{M})$ NAA to detect the effect of subculture time on cell growth. Data were reported every three days on cells fresh weight (mg).

Determination of (-)-colchicine content in Colchicum hierosolymitanum species. Calli and cell suspension were collected from test tubes and then were dried in shade at room temperature for one week. Next, they were ground using a mortar and pistle and resulted in a dry powder weighed approx. $0.5 \mathrm{~g}$ (from 5 samples) which was placed in
$50 \mathrm{ml}$ Erlenmeyer flasks. Petroleum ether $(10 \mathrm{ml} \times 2)$ was added with frequent shaking for 1 hour, followed each time by filtration using filter paper $0.45 \mu 1$. Samples (solid residues) were dried under vacuum and then extracted with $10 \mathrm{ml}$ HPLC grade dichloromethane with frequent shaking for $45 \mathrm{~min}$. Ammonium hydroxide (12.5\%), $0.5 \mathrm{ml}$ was added, followed by vigorous shaking for $15 \mathrm{~min}$, and then the mixture was left for $30 \mathrm{~min}$. Calli residues were filtered and the filtrates were saved, calli residues were washed twice with $10 \mathrm{ml}$ HPLC grade dichloromethane and then filtered. The collected filtrates and washes were combined. Organic phase was evaporated to dryness under vacuum at room temperature and then dissolved in $10 \mathrm{ml}$ of $70 \%$ ethanol. The solution was then filtered using $0.45 \mu 1$ Teflon filters; $2 \mathrm{ml}$ and transferred into $2 \mathrm{ml}$ amber HPLC vials. A portion, $50 \mu \mathrm{l}$ was injected into HPLC. Lachrom ${ }^{\circledR}$ MERCK-HITACHI HPLC equipped with quaternary gradient L-7150 pump connected to manual injector, L-7455 Diode-Array Detector, and Hibar $^{\circledR}$ MeRCK, Pre-Packed column RT $250 \times 25$, Lichrosorb $^{\circledR}$ RP-18. The mobile phase system was an isocratic blend of acetonitrle-dionized water (25:72) with 1 $\mathrm{ml}$ tri-ethyleamine, $1 \mathrm{ml}$ phosphoric acid. A UV monitor operated at $350 \mathrm{~nm}$ was used as detector. The total run time was $10 \mathrm{~min}$. All samples were analyzed against an external standard constructed calibration points and quality control (QC) samples.

Effect of nitrogen sources and concentration on callus growth and colchicine formation. This experiment was conducted to detect the effect of nitrogen source on alkaloid formation by using HPLC method. Calli $(500 \mathrm{mg})$ were subcultured on MS media with different $\mathrm{NH}_{4}{ }^{+}: \mathrm{NO}_{3}{ }^{-}$ratios at different concentrations. Ratios (30 $\mathrm{mM} \mathrm{NO}_{3}^{-}, 10: 20,20: 10$ and $\left.30 \mathrm{mM} \mathrm{NH}_{4}{ }^{+}\right)$were used at $30 \mathrm{mM}$ nitrogen, whereas ratios of $\left(60 \mathrm{mM} \mathrm{NO}_{3}{ }^{-}, 20: 40,40: 20\right.$, and $\left.60 \mathrm{mM} \mathrm{NH}_{4}{ }^{+}\right)$, were studied at $60 \mathrm{mM}$ nitrogen. Control treatment was included without any exogenous nitrogen application. Callus was subcultured to media and each treatment consisted of 20 replicate in completely randomized design. Fresh and dry weights and colchicine contents were reported after 4 weeks of inoculation.

Effect of carbohydrate source and concentration on alkaloid Production. This experiment was conducted to detect the effect of sucrose at different concentrations 0.0 , $0.1, \quad 0.2, \quad 0.3 \mathrm{M}$ on alkaloid production. Callus was subcultured to the MS media supplemented with different concentrations and data collected every other week for colchicine content using high performance liquid chromatography (HPLC) [18].

Effect of time of subculture on the colchicine production in callus and cell suspension. Callus was cultured on solid MS media supplemented with $0.54 \mu \mathrm{M}$ NAA, callus growth was monitored over 90 days of incubation. Data were reported for fresh and dry weight and colchicine contents every 5 days for one month, then for two other months at 45 , 60, 90 days. Cell suspension was cultured on liquid media supplemented with $0.54 \mu \mathrm{M}$ NAA. Data were reported for influence of growth time on fresh weight and dry weight of cell growth and colchicine content in C. heirosolymitanum during four weeks of incubation.

Influence of light/dark incubation of callus on colchicine content. Callus was cultured on solid MS media 
Table 1. Influence of Different levels of 2, 4-D in Combination with Different Levels of BA on Colchicum Hierosolymitanum Cell Growth after 30 Days of Incubation in Liquid Media

\begin{tabular}{|c|c|c|}
\hline PPGRs $(\boldsymbol{\mu M})$ 2,4-D: BA & Fresh Weight $(\mathbf{g})$ & Color \\
\hline \hline $0.00: 0.00$ & $2.13 \mathrm{bc}{ }^{*}$ & $89 \%$ brownish \\
\hline $00: 2.22$ & $2.34 \mathrm{bc}$ & $100 \%$ black \\
\hline $00: 3.11$ & $2.35 \mathrm{abc}$ & $89 \%$ brownish \\
\hline $00: 9.00$ & $1.92 \mathrm{c}$ & $100 \%$ black \\
\hline $0.45: 00$ & $2.50 \mathrm{abc}$ & $100 \%$ yellowish \\
\hline $0.45: 2.22$ & $2.74 \mathrm{ab}$ & $90 \%$ brownish \\
\hline $0.45: 3.11$ & $2.48 \mathrm{abc}$ & $90 \%$ brownish \\
\hline $0.45: 9.00$ & $3.04 \mathrm{a}$ & $80 \%$ brownish \\
\hline LSD & 0.695 & \\
\hline
\end{tabular}

* Means having different letters in each column are significantly different according to the least significant different (LSD $\leq 0.05$ ).

supplemented with $0.54 \mu \mathrm{M}$ NAA in the light and dark conditions, Data were reported for fresh and dry weight and colchicine contents in both light and dark conditions.

Experimental Design and Statistical Analysis. Each experiment in this study was set up as a completely randomized design (CRD) with 5 replications. Collected data were statistically analyzed using Genstat software (Rothamsted Experimental station, 2002). Means were separated according to the least significant difference (LSD) at 0.05 level of probability.

\section{RESULTS AND DISCUSSION}

Cell Suspension. Calli clumps from the fourth generation grown on $0.45 \mu \mathrm{M} 2$, 4-D provided good cell source to initiate cell suspension culture. Lee et al. [24] who worked on Oryza sativa L. used friable callus transferred to liquid medium supplemented with the same PGRs to form cell suspension culture. Higher concentration $9 \mu \mathrm{M}$ of BA with $0.45 \mu \mathrm{M} 2,4-\mathrm{D}$ resulted in higher cells fresh weight (Table 1). After two weeks of incubation large cell clumps forming callus grown in all treatments of 2,4-D and BA was hard and brownish in color; except $0.45 \mu \mathrm{M}$ 2,4-D alone treatment (Table 1). Sakhanokho et al. [25] found variation in callus color in liquid media culture from yellowish-green to black in Gossypium barbadense L. Lee et al. [24] showed that the best responses in growth of cells, no browning and aggregation of cells during suspension periods of culture depend on plant cultivar.

On the other hand, control and $0.45 \mu \mathrm{M}$ NAA combinations with BA had no effect on cell growth (Table 2). Despite the fact that no shoot formation developed in all treatments of NAA and BA, embryogenesis occurred on PGRfree media and on $2.22 \mu \mathrm{M}$ BA supplemented media. (Table 2). Phenolic browning appeared after two weeks of incubation except in control treatment (Table 2). Hyoscyamus muticus gave the highest incidence of biomass accumulation of cell suspension and alkaloid production at combination ratios between $5.4 \mu \mathrm{M}$ BA and $4.4 \mu \mathrm{M}$ NAA [26].

Time of Subculturing for callus and cell suspension culture. Callus width, length height increased with time until
Table 2. Influence of Different Levels of NAA in Combination with Different Levels of BA on Colchicum Hierosolymitanum Cell Growth after 30 Days of Incubation in Liquid Media

\begin{tabular}{|c|c|c|}
\hline PGRs $(\boldsymbol{\mu M})$ NAA: BA & Fresh Weight $(\mathbf{g})$ & Color \\
\hline \hline $0.00: 0.00$ & $1.50 \mathrm{~b} *$ & $100 \%$ yellowish \\
\hline $00: 2.22$ & $1.15 \mathrm{bc}$ & $78 \%$ brownish \\
\hline $00: 3.11$ & $1.04 \mathrm{bcd}$ & $100 \%$ black \\
\hline $00: 9.00$ & $0.79 \mathrm{~cd}$ & $80 \%$ brownish \\
\hline $0.54: 00$ & $1.21 \mathrm{bc}$ & $76 \%$ brownish \\
\hline $0.54: 2.22$ & $1.52 \mathrm{~b}$ & $76 \%$ brownish \\
\hline $0.54: 3.11$ & $0.51 \mathrm{~d}$ & $90 \%$ brownish \\
\hline $0.54: 9.00$ & $3.91 \mathrm{a}$ & $78 \%$ brownish \\
\hline LSD & 0.567 & \\
\hline
\end{tabular}

*Means having different letters in each column are significantly different according to the least significant different (LSD $\leq 0.05$ ).

reach the peak at 60 days period (Table 3). However, callus width and length had been declined after 90 days in culture (Table 3). This indicates that many factors influence on callus growth, such as depletion of essential nutrients, water loss from the medium and accumulation of toxic substances. Therefore, the healthy $C$. hierosolymitanum calli should be transferred to fresh medium after 6-8 weeks to maintain the viability and healthy growth. Gopi and Vatsala [8], who worked on Gymnema sylvestre, reported maximum biomass yield during $21^{\text {st }}$ to $27^{\text {th }}$ day on solid media.

Cells cultures were demonstrated on liquid media by recording cell fresh weight every three days. Results showed that the cells had lag phase of 9 days followed by an exponential growth phase until they reached the maximum growth (Table 4). In addition, the time for subculturing the cells into new fresh liquid media was determined to be after 27 days of incubation. Growth was declined because the cells entered a stationary phase. Cell growth declined after 27 days (Table 4) and this could be attributed to the depletion of nutrients, accumulation of toxic products and growth inhibitors [27]. Gopi and Vatsala [8] reported that maximum biomass yield on liquid media after $18^{\text {th }}$ to $24^{\text {th }}$ day of incubation in Gymnema sylvestre.

Identification of (-)-colchicine alkaloid. Effect of nitrogen sources and concentration on callus growth and alkaloid formation. The optimal nitrogen concentration in the medium was required for both callus growth and colchicine formation (Table 5, Fig 1). These results showed that low colchicine content of $0.002 \mathrm{mg} \mathrm{g}^{-1} \mathrm{DW}$ was detected on media without any source of nitrogen. In addition, $30 \mathrm{mM}$ $\mathrm{NH}_{4}{ }^{+}$total nitrogen resulted in highest colchicine content of $0.070 \mathrm{mg} \mathrm{g}^{-1} \mathrm{DW}$. Yang et al. [28] reported that the highest flavonoid content in Glycyrrhiza uralensis was obtained when the ratio of $\mathrm{NH} 4+/ \mathrm{NO} 3-$ in the medium was decreased to the half, they found that $\mathrm{NH}$; inhibited the callus growth and flavonoid formation of $\mathrm{G}$. uralensis.

Effect of carbohydrate source and concentration on alkaloid production. The presence of (-)-colchicine in callus was affected by concentration of sucrose and period of incubation on media (Table 6). (-)-Colchicine alkaloid was 
Table 3. Influence of Subculture Time on Colchicum Heirosolythanium Callus Growth Over 90 Days Incubation on Solid MS Media

\begin{tabular}{|c|c|c|c|c|c|}
\hline Time Subculture (Days) & Callus Width (cm) & Callus Length (cm) & Callus Height (cm) & Fresh Weight (g) & Color \\
\hline 5 & $1.14 \mathrm{~d}^{*}$ & $0.64 \mathrm{~d}$ & $0.38 \mathrm{~d}$ & $0.34 \mathrm{e}$ & $100 \%$ yellowish \\
\hline 10 & $1.28 \mathrm{~d}$ & $0.76 \mathrm{~cd}$ & $0.38 \mathrm{~d}$ & $0.47 \mathrm{de}$ & $100 \%$ yellowish \\
\hline 15 & $1.24 \mathrm{~d}$ & $0.94 \mathrm{c}$ & $0.44 \mathrm{~cd}$ & $0.64 \mathrm{de}$ & $100 \%$ yellowish \\
\hline 20 & $1.62 \mathrm{c}$ & $1.32 \mathrm{~b}$ & $0.50 \mathrm{~cd}$ & $0.73 \mathrm{~d}$ & $100 \%$ yellowish \\
\hline 25 & $1.76 \mathrm{bc}$ & $1.46 \mathrm{ab}$ & $0.70 \mathrm{bc}$ & $1.09 \mathrm{c}$ & $100 \%$ yellowish \\
\hline 30 & $1.86 \mathrm{ab}$ & $1.46 \mathrm{ab}$ & $0.90 \mathrm{ab}$ & $1.19 \mathrm{ab}$ & $100 \%$ yellowish \\
\hline 45 & $1.84 \mathrm{ab}$ & $1.64 \mathrm{a}$ & $1.02 \mathrm{a}$ & $1.27 \mathrm{bc}$ & $100 \%$ yellowish \\
\hline 60 & $1.96 \mathrm{a}$ & $1.72 \mathrm{a}$ & $1.02 \mathrm{a}$ & $1.47 \mathrm{ab}$ & $100 \%$ yellowish \\
\hline 90 & $1.78 \mathrm{~b}$ & $1.52 \mathrm{ab}$ & $1.04 \mathrm{a}$ & $1.78 \mathrm{a}$ & $100 \%$ yellowish \\
\hline LSD & 0.151 & 0.285 & 0.267 & 0.339 & \\
\hline
\end{tabular}

* Means having different letters in each column are significantly different according to the least significant different (LSD $\leq 0.05)$.

Table 4. Cell Growth of Colchicum Hierosolymitanum Over 30 Days Incubation in Liquid Media Supplemented with $0.54 \mu M$ NAA

\begin{tabular}{|c|c|c|c|}
\hline \multicolumn{5}{|c|}{ Parameters } \\
\hline Time (Days) & Initial Weight (g) & Recorded Weight (g) & Difference (g) \\
\hline 3 & $1.05 \mathrm{~b}^{*}$ & $0.76 \mathrm{f}$ & -0.29 \\
\hline 6 & $1.05 \mathrm{~b}$ & $0.91 \mathrm{e}$ & -0.14 \\
\hline 9 & $1.36 \mathrm{a}$ & $1.05 \mathrm{ed}$ & -0.31 \\
\hline 12 & $1.05 \mathrm{~b}$ & $1.23 \mathrm{~cd}$ & +0.18 \\
\hline 15 & $1.01 \mathrm{~b}$ & $1.29 \mathrm{c}$ & +0.28 \\
\hline 18 & $1.05 \mathrm{~b}$ & $1.31 \mathrm{c}$ & +0.26 \\
\hline 21 & $1.01 \mathrm{~b}$ & $1.34 \mathrm{bc}$ & +0.33 \\
\hline 24 & $1.01 \mathrm{~b}$ & $1.41 \mathrm{bc}$ & +0.40 \\
\hline 27 & $1.45 \mathrm{a}$ & $1.85 \mathrm{a}$ & +0.40 \\
\hline 30 & $1.12 \mathrm{~b}$ & $1.73 \mathrm{ab}$ & +0.61 \\
\hline LSD & 0.233 & 0.398 & \\
\hline
\end{tabular}

*Means having different letters in each column are significantly different according to the least significant different (LSD $\leq 0.05)$.

Table 5. Influence of Various $\left(\mathrm{NH}_{4}{ }^{+}: \mathrm{NO}_{3}{ }^{-}\right)$Ratios on Callus Fresh Weight, Dry Weight and Colchicine Content in Callus of Colchicum Hierosolymitinum after 30 days of Incubation

\begin{tabular}{|c|c|c|c|}
\hline \multicolumn{3}{|c|}{ Parameters } \\
\hline $\mathbf{N H}_{4}{ }^{+}: \mathbf{N O}_{\mathbf{3}(\mathbf{m M})}$ & Fresh Weight (g) & Dry Weight (g) & Colchicine Content (mg/g) \\
\hline $0.00: 0.00$ & $1.19 \mathrm{~b}^{*}$ & $0.13 \mathrm{bc}$ & 0.002 \\
\hline $0.00: 30.0$ & $1.26 \mathrm{ab}$ & $0.17 \mathrm{a}$ & 0.005 \\
\hline $10.0: 20.0$ & $1.39 \mathrm{ab}$ & $0.16 \mathrm{a}$ & 0.004 \\
\hline $20.0: 10.0$ & $1.37 \mathrm{ab}$ & $0.15 \mathrm{ab}$ & 0.013 \\
\hline $30.0: 0.00$ & $1.53 \mathrm{a}$ & $0.17 \mathrm{a}$ & 0.030 \\
\hline $0.00: 60.0$ & $0.71 \mathrm{c}$ & $0.11 \mathrm{~cd}$ & 0.051 \\
\hline $20.0: 20.0$ & $0.78 \mathrm{c}$ & $0.11 \mathrm{~cd}$ & 0.004 \\
\hline $40.0: 20.0$ & $0.65 \mathrm{c}$ & $0.09 \mathrm{~d}$ & 0.004 \\
\hline $60.0: 0.00$ & $0.85 \mathrm{c}$ & $0.10 \mathrm{~cd}$ & 0.033 \\
\hline LSD & 0.322 & & 0.007 \\
\hline
\end{tabular}

*Means having different letters are significantly different according to the least significant different ( $\mathrm{LSD} \leq 0.05)$. 


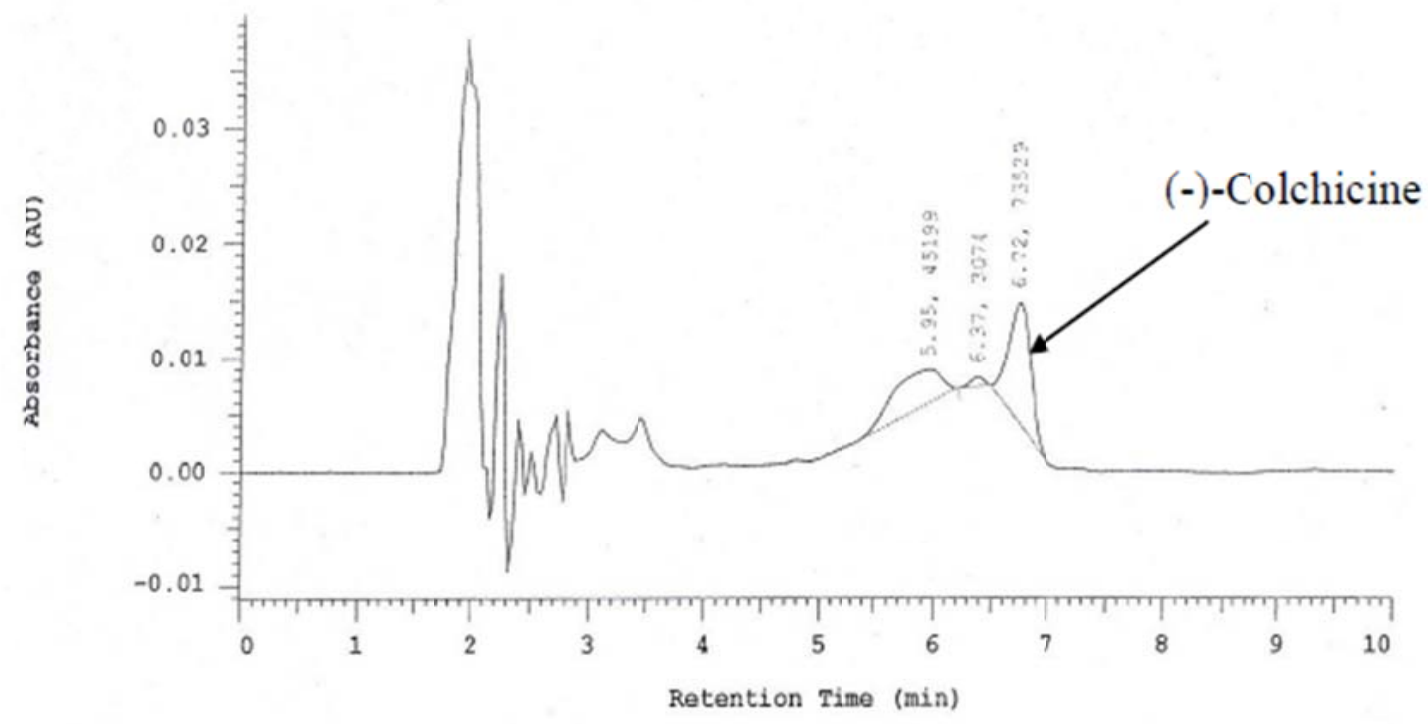

Fig. (1). HPLC analysis of (-)- colchicine in Colchicum hierosolymitamun callus grown under dark conditions on media supplemented with $\mathrm{NH}_{4}^{+}: \mathrm{NO}_{3}{ }^{-}(30.0: 0.00 \mathrm{mM})$ after 30 days of incubation.

Table 6. Influence of Different Concentrations of Sucrose on Colchicum Hierosolymitunm. Callus Fresh Weight, Dry Weight and Colchicine Content from Calli Grown on MS Solid Media within a Time

\begin{tabular}{|c|c|c|c|c|}
\hline \multicolumn{5}{|c|}{ Parameters } \\
\hline Time (Weeks) & Concentrations (M) & Fresh Weight (g) & Dry Weight (g) & Colchicine Content (mg/g) \\
\hline \hline 2 & 0.0 & $0.51 \mathrm{e}^{*}$ & $0.06 \mathrm{f}$ & 0.000 \\
\hline 2 & 0.1 & $0.55 \mathrm{~d}$ & $0.12 \mathrm{~d}$ & 0.002 \\
\hline 2 & 0.2 & $0.72 \mathrm{~b}$ & $0.14 \mathrm{c}$ & 0.017 \\
\hline 2 & 0.3 & $0.80 \mathrm{a}$ & $0.18 \mathrm{~b}$ & 0.008 \\
\hline 4 & 0.0 & $0.46 \mathrm{f}$ & $0.05 \mathrm{f}$ & 0.090 \\
\hline 4 & 0.1 & $0.65 \mathrm{c}$ & $0.11 \mathrm{e}$ & 0.014 \\
\hline 4 & 0.2 & $0.64 \mathrm{c}$ & $0.12 \mathrm{~d}$ & 0.011 \\
\hline
\end{tabular}

*Means having different letters in each column are significantly different according to the least significant different (LSD $\leq 0.05)$.

higher $\left(0.090 \mathrm{mg} \mathrm{g}^{-1} \mathrm{DW}\right)$ at $0.1 \mathrm{M}$ of sucrose after 4 weeks incubation while no colchicine was identified after 2 weeks on sucrose free media. This indicates that high concentration $(0.1 \mathrm{M})$ of sucrose could induce osmotic stress and enhance accumulation of (-)-colchicine in callus and cells of C.hierosolymitanum. In Glycyrrhiza uralensis fructose was superior to sucrose for callus growth and flavonoid formation [28]. Xue et al. [29] reported that, 3\% sucrose was best for synthesis of crocin in saffron (Crocus sativus) callus.

Effect of time of subculture on the colchicine production in callus and cell suspension. Colchicine was identified and content determined in callus and in cell suspension cultures. Maximum production of colchicine, $0.235 \mathrm{mg} \mathrm{g}^{-1} \mathrm{DW}$ was obtained in callus extracts of 60 days old callus grown under dark conditions (Table 7, Fig 2). (-)-Colchicine content decreased after 90 days and this was accompanied by increased phenolic browning. Extracts of grown suspended cells (Table 8, Fig 3) showed that high colchicine content of $0.012 \mathrm{mg} \mathrm{g}^{-1}$ DW was obtained at the start of culture after the first week during the lag phase. In Vernonia cinerea cell suspension growth and alkaloid contents were maximal in 20-day-old cultures and alkaloid contents were $1.15 \mathrm{mg} / \mathrm{g}$ [30]. Gopi and Vatsala [8] recorded that the gymnemic acids and gymnemagenin were present in cultured cells in Gymnema sylvestre.

Influence of light/dark incubation on callus colchicine content. The presence of colchicine alkaloid is affected by the photoperiod incubation (Table 9). The variation in alkaloid content of callus incubated under dark $\left(0.095 \mathrm{mg} \mathrm{g}^{-1}\right.$ $\mathrm{DW})$ and light $\left(0.070 \mathrm{mg} \mathrm{g}^{-1} \mathrm{DW}\right)$ condition was studied, and the results indicates that light may stimulate phenolic compound furthermore and may have influenced colchicine biosynthesis and accumulation in callus culture. It is also known that (-)-colchicine is not stable under light and may have converted after been biosynthesized into lumicolchicines, known light derived products of colchicine, upon light exposure. On the other hand, the content of (-)colchicine in the wild type of Colchicum and cultivation studies was reported. Alali et al. [19] determined the amounts of colchicine present in two wild Jordanian species of colchicum, namely, C. steveni Kunth which was found to contain the largest amount of colchicine $(0.204 \mathrm{mg} / \mathrm{g})$ dry 
Table 7. Callus Growth and Colchicine Content of Colchicum Hierosolymitanum Over 90 Days Incubation in Solid Media Supplemented with $0.54 \mu \mathrm{M}$ NAA

\begin{tabular}{|c|c|c|c|}
\hline \multicolumn{3}{|c|}{ Parameters } \\
\hline Time (Days) & Fresh Weight (g) & Dry Weight (g) & Colchicine Content (mg/g DW) \\
\hline \hline 5 & $0.62 \mathrm{c}^{*}$ & $0.06 \mathrm{~g}$ & 0.088 \\
\hline 10 & $0.58 \mathrm{c}$ & $0.78 \mathrm{a}$ & 0.015 \\
\hline 15 & $0.73 \mathrm{c}$ & $0.11 \mathrm{f}$ & 0.003 \\
\hline 20 & $0.58 \mathrm{c}$ & $0.09 \mathrm{~g}$ & 0.006 \\
\hline 25 & $1.39 \mathrm{ab}$ & $0.12 \mathrm{e}$ & 0.056 \\
\hline 30 & $1.71 \mathrm{a}$ & $0.16 \mathrm{~d}$ & 0.075 \\
\hline 45 & $1.09 \mathrm{bc}$ & $0.12 \mathrm{e}$ & 0.235 \\
\hline 60 & $1.15 \mathrm{~b}$ & $0.18 \mathrm{c}$ & 0.005 \\
\hline 90 & $1.69 \mathrm{a}$ & $0.23 \mathrm{~b}$ & 0.034 \\
\hline
\end{tabular}

*Means having different letters in each column are significantly different according to the least significant different (LSD $\leq 0.05$ ).

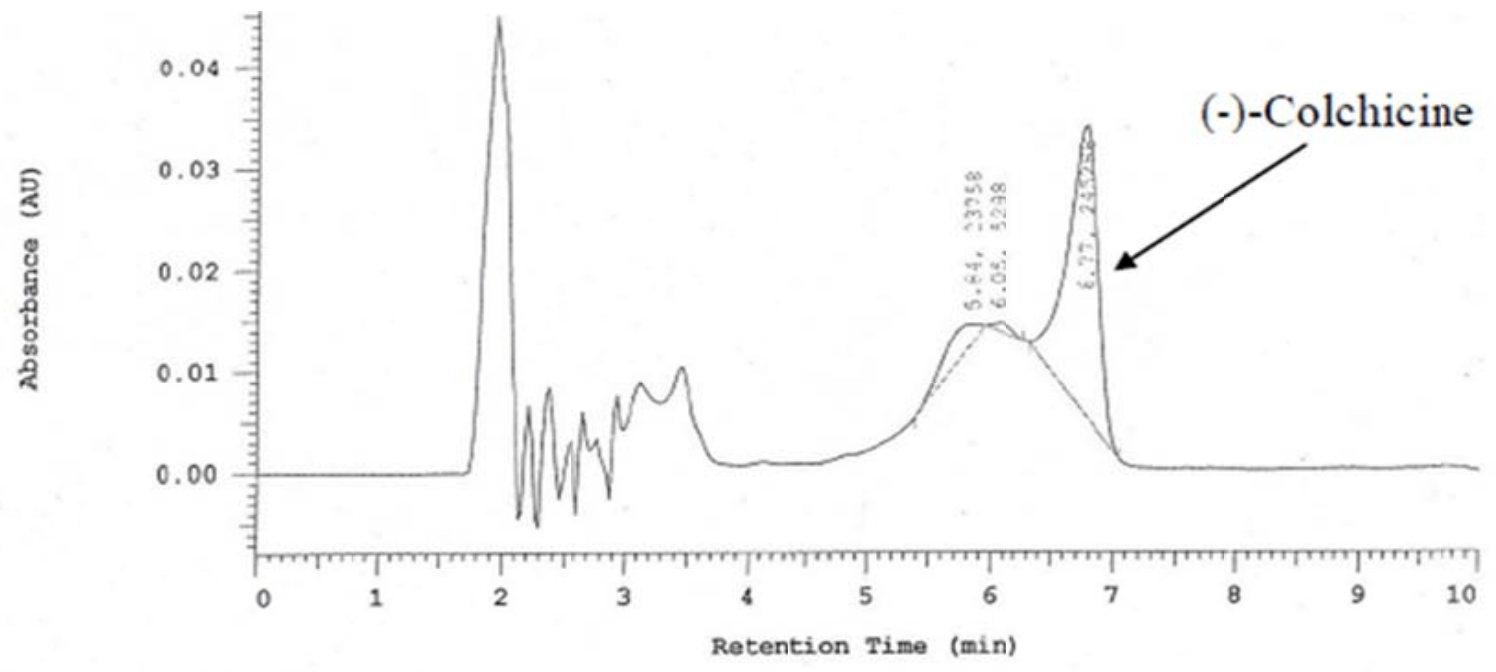

Fig. (2). HPLC analysis of (-)- colchicine in Colchicum hiersolymitanum callus grown under dark condition after 60 days of incubation on media supplemented with $0.54 \mu \mathrm{M}$ NAA.

Table 8. Influence of Growth Time on Fresh Weight and Dry Weight of Cell and Colchicine Content in Colchicum Heirosolymitanum During Four Weeks Incubation on Liquid Media Supplemented with $0.54 \mu \mathrm{M}$ NAA

\begin{tabular}{|c|c|c|c|}
\hline \multicolumn{3}{|c|}{ Parameters } \\
\hline TIME (Weeks) & Fresh Weight (g) & Dry Weight (g) & Colchicine Content mg/g \\
\hline \hline 1 & $1.12 \mathrm{a}^{*}$ & $0.22 \mathrm{a}$ & 0.012 \\
\hline 2 & $0.97 \mathrm{a}$ & $0.24 \mathrm{a}$ & 0.008 \\
\hline 3 & $1.09 \mathrm{a}$ & $0.19 \mathrm{a}$ & 0.005 \\
\hline 4 & $1.25 \mathrm{a}$ & $0.23 \mathrm{a}$ & 0.011 \\
\hline LSD & 0.435 & 0.059 & \\
\hline
\end{tabular}

*Mean having different letters in each column are significantly different according to the least significant different (LSD $\leq 0.05)$. 


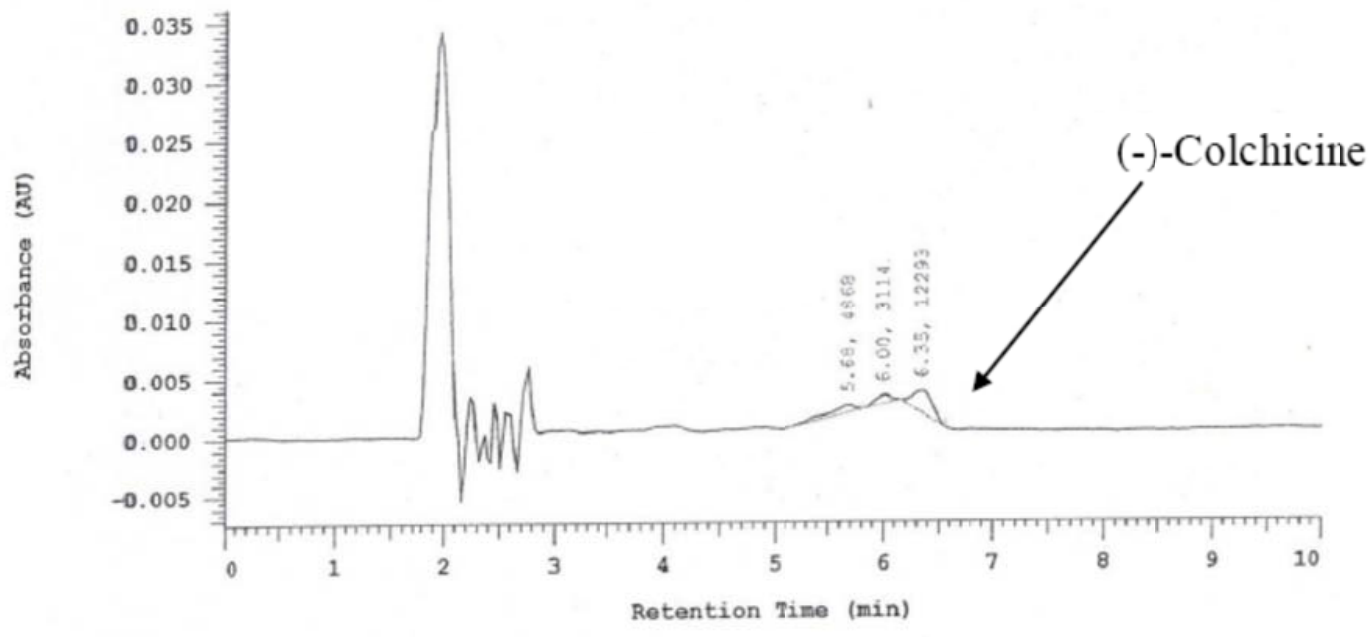

Fig. (3). HPLC analysis of (-)- colchicine in Colchicum hierosolymitanum suspended cells grown under dark on media supplemented with0.54 $\mu \mathrm{M}$ NAA after one week of incubation.

Table 9. Influence of Light/Dark Incubation of Callus on Colchicine Content in Colchicum Heirosolymitanum after 30 Days of Incubation

\begin{tabular}{|c|c|c|c|}
\hline \multicolumn{3}{|c|}{ Parameters } \\
\hline Position & Fresh Weight (g) & Dry Weight (g) & Colchicine Content (mg/g) \\
\hline \hline Light & $2.63 \mathrm{a}^{*}$ & $0.22 \mathrm{a}$ & 0.07 \\
\hline Dark & $2.49 \mathrm{a}$ & $0.26 \mathrm{a}$ & 0.095 \\
\hline LSD & 1.253 & 0.051 & \\
\hline
\end{tabular}

*Means having different letters in each column are significantly different according to the least significant different (LSD $\leq 0.05$ ).

weight in the leaves and C. hierosolymitanum Feibrun in which corms showed the highest colchicine content 0.126 $\mathrm{mg} / \mathrm{g}$ dry weight. Furthermore Al-Fayyad et al. [5] found that the highest colchicine content in corms of cultivated $C$. hierosolimitanum and C. tunicatum were at maturity stage $0.766 \mathrm{mg} / \mathrm{g}$ and $0.688 \mathrm{mg} / \mathrm{g}$ dry weight, respectively.

The presence of colchicine in $C$. hierosolymitanum grown under in vitro conditions (chemical composition of media, temperature, light, PGR and media PH) indicates that these tissues have the capability of producing colchicine under controlled microenvironmental conditions. Therefore the in vitro production of secondary metabolites of Colchicum could be manipulated and enhanced with appropriate chemical and physical conditions to attain the optimal requirements.

\section{CONCLUSIONS}

Cell suspension culture was successfully started in colchicum hierosolymitanum from callus. Colchicine alkaloid was identified and content determined in callus and in cell suspension cultures of in vitro grown $C$. hierosolymitanum by performing HPLC analysis. In vitro production of secondary metabolites of Colchicum could be manipulated and enhanced with appropriate chemical and physical conditions to attain the optimal requirements.

\section{CONFLICT OF INTEREST}

The authors confirm that this article content has no conflicts of interest.

\section{ACKNOWLEDGEMENT}

Declared none.

\section{REFERENCES}

[1] Poutaraud, A.; Girardin, P. Influence of chemical characteristics of soil on mineral and alkaloid seed contents of Colchicum autumnal. Environ. Exper. Bot., 2005, 54, 101-108.

[2] Gabrscek, L.; Lesnicar, G.; Krivec, B.; Voga, G.; Sibance, B Blatnik, J.; Jagodic, B., Accidental poisoning with autumn crocus. J. Toxicol., 2004, 42, 85-88.

[3] Sannohe, S.; Makino, Y.; Kita, T.; Kuroda, N.; Shinozuka, T., Colchicine poisoning resulting from accidental ingestion of meadow saffron (Colchicum autumnale). J. Forensic Sci., 2002, 47, $1-6$.

[4] Inchem. Colchicum autumnale L. http://www.inchem.org/documents/pims/plant/pim142.htm, 1-33 [Accessed February 23 2006].

[5] Al-Fayyad, M.; Alali, F.; Alkofahi, A.; Tell, A. Determination of Colchicine content in Colchicum hierosolymitnum and Colchicum tunicatum under cultivation. Nat. Prod. Lett., 2002, 16, 395-400.

[6] Chirangini, P.; Sharma, G.J. In vitro propagation and microrhizome induction in Zingiber cassumunar (Roxb.) - an antioxidant - rich medicinal plant. J. Food Agric. Environ., 2005, 3,139-142.

[7] Chang, C.h.; Chen, Ch. T.; Tsai, Yu. C.; Chang, Wei. Ch. A tissue culture protocol for propagation of a rare plant, Lilium speciosum Thunb. var. gloriosoides Baker. Bot. Bull. Acad. Sin., 2000, 41, 139-142.

[8] Gopi, C.; Vatsala, T.M., In vitro studies on effects of plant growth regulators on callus and suspension culture biomass yield from Gymnema sylvestre R. Br. Afr. J. Biotechnol., 2006, 5, 1215-1219.

[9] Baumert, A.; Gröger, D.; Kuzovkina, I.N.; Reisch, J. Secondary metabolites produced by callus cultures of various Ruta species. Plant Cell, Tissue Organ Cult., 1992, 28,159-162.

[10] Dollery, C.; Boobis, A.; Rawlings. M.; Thomas S.; Wilkings M. Therapeutic drugs. Churchill Livingstone: UK, 1999, 1, pp, 320-322. 
[11] Trease, G. E; Evas, W. C. Trease and Evans' Pharmacognosy, $13^{\text {th }}$ ed., Bailiere Tindall: London and Philadelphia, 1989, pp. 600-603.

[12] Herbert, R.B.; Knagg, E. The biosynthesis of the phenethylisoquinoline alkaloid, colchicine from cinnamaldehyde and dihydrocinnamaldehyde. Tetrahedron Lett., 1986, 27, 1099-1102.

[13] Terkeltaub, R.A. Clinical practice. Gout. N. Engl. J. Med., 2003, 349, 1647-1655.

[14] Drenth, J.P.; Meer, J.W.V.D. Hereditary periodic fever. N. Engl. J. Med., 2001, 345, 1748-1757.

[15] Sakane, T.; Takeno, M. Novel approaches to Behçet disease. Expert Opin. Invest. Drugs, 2000, 9, 1993-2005.

[16] Alexander, P.; Brigitte, N.; Meinhart Z. Immunoassays for the quantitative determination of Colchicine. Planta Medica., 1994, 60, 77-83.

[17] Ondra, P.; Valka, I.; Vicar, J.; Sutlupinar, N.; Simanek V. Chromatographic determination of constituents of the genus Colchicum (Liliaceae). J. Chromatography, 1995, 704, 351-356.

[18] Sütlüpinar, N.; Husek, A.; Potěšilova, H.; Dvořáčkova, S.; Hanuš, V.; Sedmera, P.; Šimánek, V. Alkaloids and phenolics of Colchicum cilicium. Planta Medica., 1989, 54, 243-245.

[19] Alali, F.; Tawaha, K.H.; Qasaymeh, R. M. Determination of colchicine Colchicum steveni and C. hierosolymitanum (Colchicaceae), comparison between two analytical methods. Phytochem. Anal., 2004, 15, 27-29.

[20] Hayashi, T; Yoshida, K; Sano, K. Formation of alkaloids in suspension cultured Colchicum autumnale. Phytochemistry, 1988, 27, 371-1374

[21] Yoshida, K.; Hayashi, T.; Sano, K. Colchicine precursors and the formation of alkaloids in suspension cultured Colchicum autumnale. Phytochemistry, 1988, 27, 1375-1378.

[22] Ghosh, B.; Mukherjee, S.; Jha, T.B.; Jha, S., Enhanced colchicine production in root cultures of Gloriosa superba by direct and indirect precursors of the biosynthetic pathway. Biotechnol. Lett., 2002, 24, 231-234.

[23] Murashige, T.; Skoog, F. A revised medium for rapid growth and bioassay with tobacco tissue cultures. Physiol. Plant, 1962, 15, 473-497.

[24] Lee, T. J.; Shultz, R. W.; Bowdoin, L. H.; Thompson, W. F. Establishment of rapidly proliferating rice cell suspension culture and its characteriazation by fluorescence-activated cell sorting analysis. Plant Mol. Biol. Rep., 2004, 22, 259-267.

[25] Sakhanokho, H. F.; Zipf, A.; Rajasekaran, K.; Saha, S.; Sharma, G. C. Induction of highly embryogenic calli and plant regeneration in upland (Gossypium hirsutum L.) and pima (Gossypium barbadense L.) cottons. Crop. Sci., 2001, 41, 1235-1240.

[26] Aly, U. I.; El-Shabrawi, H. M.; Hanafy, M. Impact of culture conditions on alkaloid production from undifferentiated cell. Aust. J. Basic Appl. Sci., 2010, 4, 4717-4725.

[27] Smith, H., Ed. The molecular biology of plant cells. In chapter (Plant cell culture), Berkeley, University of California Press, 1977 15, pp. 395- 400

[28] Yang, S.H.; Tao, J.; Liu, X.F.; Guo, D.A.; Zheng, J.H., Effects of carbon source and nitrogen source on callus growth and flavonoid content in Glycyrrhiza uralensis. Zhongguo Zhang yoa Za zhi, 2006, 31, 1857-1859.

[29] Xue, L; Zhigang, G; Ruizhi, L. Effects of culture conditions, carbon source and regulators on saffron callus growth and crocin accumulation in the callus. Tsinghua Sci. Technol., 2002, 7, 448453.

[30] Maheshwari, P; Songara, B; Kumar, S; Jain, P; Srivastava, K; Kumar, A. Alkaloid production in Vernonia cinerea, Callus, cell suspension and root cultures. Biotechnol. J., 2007, 8, 1026-1032.

(C) Daradkeh et al.; Licensee Bentham Open.

This is an open access article licensed under the terms of the Creative Commons Attribution Non-Commercial License (http://creativecommons.org/licenses/by$\mathrm{nc} / 3.0 /$ ), which permits unrestricted, non-commercial use, distribution and reproduction in any medium, provided the work is properly cited. 